\title{
ANALISIS KOMPARASI USAHATANI PADI SAWAH SISTEM TANAM SRI DAN KONVENSIONAL DI DESA BUKIT PENINJAUAN I KECAMATAN SUKARAJA KABUPATEN SELUMA
}

\author{
(COMPARATION ANALYSIS OF PADDY FARMING BETWEEN \\ SYSTEM OF RICE INTENSIFICATION AND CONVENTIONAL SYSTEM \\ IN BUKIT PENINJAUAN I VILLAGE SUBDISTRICT FO SUKARAJA \\ DISTRICT OF SELUMA)
}

\author{
Evi Tinubaya L, Basuki Sigit Priyono, dan Witman Rasyid \\ Jurusan Sosial Ekonomi Pertanian \\ Fakultas Pertanian Universitas Bengkulu
}

\begin{abstract}
SRI is rice cultivation technique which able increase rice productivity by modify plant management, soil, water, and nutrients. The goal of this research are to determine and analyze the factors which influence the production, and to know the revenue between SRI method and Conventional system of rice farm. Rice farm revenueby SRI method is $R p$ 4.199.923,53 /Ut/Mt or Rp 6.287.124,48/Ha/Mt while the farmers in convensional system is Rp 4.761.240,60/Ut/Mt or Rp 6.343.424,53/Ha/Mt. "Cobb-douglass" analysis used to determine someproduction factors which invluence the production. The study result explain that factorwhich influence to the production of SRI system is land area, while the amount of seeds, organic fertilizer, organic pesticides, and the labor had no effect in rice farm production. Where as the factorswhich significantly influence to the productionof conventional system are land area and labor, while the amount of seeds, chemical fertilizer, and chemical pesticides had no effect in rice farm production.
\end{abstract}

Key words: SRI method, Production factors, Rice farm revenue

\section{PENDAHULUAN}

Beras merupakan komoditas penting dan strategis bagi Indonesia karena merupakan makanan pokok dan sumber perolehan karbohidrat bagi kelangsungan hidup manusia. Upaya diversifikasi pangan tampaknya masih belum mampu mengubah preferensi penduduk terhadap beras. Berkaitan dengan hal ini, dalam jangka panjang beras akan tetap menjadi pangan pokok penduduk indonesia, sehingga kebijakan produksi beras akan tetap menjadi kebijakan inti dalam pembangunan pertanian. Seiring dengan perjalanan waktu, kendala dalam memenuhi produksi beras semakin berat. Sehingga untuk memenuhi kebutuhan produksi beras dalam jangka panjang, maka perlu dipilih tehnologi penanaman padi yang dapat meningkatkan produksi tanaman padi

Evi Tinubaya L, Basuki Sigit Priyono, dan Witman Rasyid. Analisis ... | 188 
dengan upaya mengurangi metode tanam padi biasa yang bersifat anorganik seperti penerapan metode tanam SRI yang menunjang produksi maksimal.

Penduduk di kabupaten Seluma sebagian besar menggantungkan hidupnya di sektor pertanian khususnya tanaman pangan seperti padi sawah. Oleh karena itu pendapatan petani dari sektor pertanian perlu ditingkatkan. Upaya yang dilakukan pemerintah Kabupaten Seluma saat ini yaitu dengan mengadakan program peningkatan hasil produksi padi sawah dengan sistem tanam SRI di Desa Bukit Peninjauan I. Sistem tanam SRI adalah teknik budidaya padi dengan cara mengubah pengelolaan tanaman, tanah, air dan unsur hara. Awal mula metode SRI dikembangkan pada tahun 2009 oleh Dinas Pertanian Kabupaten Seluma melalui pembinaan gabungan kelompok tani di Desa Bukit Peninjauan I Kecamatan Sukaraja Kabupaten Seluma. Usaha penerapan sistem tanam SRI di Desa Bukit Peninjauan I ditujukan untuk mendapatkan produksi yang tinggi dengan biaya yang sedikit. Namun untuk mendapatkan produksi yang tinggi ini, petani harus memanfaatkan faktor produksi yang ada dengan tepat. Ada beberapa faktor produksi yang perlu mendapat perhatian petani agar produksi yang diharapkan dapat tercapai. Faktor -faktor tersebut antara lain luas lahan, benih, pestisida, pupuk, dan tenaga kerja.

\section{METODE PENELITIAN}

Populasi dalam penelitian ini meliputi petani yang melakukan usahatani padi sawah dengan sistem tanam metode SRI dan metode konvensional. Untuk penarikan jumlah responden dilakukan secara proportional dengan terlebih dahulu memisahkan berdasarkan strata luas lahan yang kemudian diacak dan selanjutnya ditentukan dengan memberi tanda dari setiap calon responden yang diinginkan (Teguh, 2005). Dalam menggunakan teknik sampel stratifikasi proposional yang populasinya sebanyak 75 orang petani padi metode konvensional, jumlah sampel responden yang diambil sebanyak $50 \%$ atau 38 petani dan 65 petani metode SRI, jumlah sampel responden yang diambil sebanyak $50 \%$ atau 33 petani.

\section{Analisis Fungsi Produksi}

Untuk menganalisis pengaruh penggunaan faktor produksi terhadap produksi usahatani padi sawah digunakan fungsi produksi Cobb Douglas, secara matematika dapat diformulasikan sebagai berikut:

$$
\mathbf{Y}=\mathbf{a} \mathbf{X}_{1}{ }^{\mathrm{b} 1} \mathbf{X}_{2}{ }^{\mathrm{b} 2} \mathbf{X}{ }^{\mathrm{b} 3} \mathbf{X}_{4}{ }^{\mathrm{b} 4} \mathbf{X}_{5}{ }^{\mathrm{b} 5}
$$

Agar fungsi produksi Cobb Douglas dapat diestimasi maka digunakan metode kuadrat terkecil dengan mengubah fungsi tersebut menjadi bentuk logaritmatik sebagai berikut:

$$
\operatorname{Ln} Y=\operatorname{Ln} a+b_{1} \operatorname{Ln} X_{1}+b_{2} \operatorname{Ln} X_{2}+b_{3} \operatorname{Ln} X_{3}+b_{4} \operatorname{Ln} X_{4}+b_{5} \operatorname{In} X_{5}+U
$$


dimana $\mathrm{Y}$ adalah Hasil produksi, $\mathrm{X}_{1}$ adalah Luas Lahan $(\mathrm{Ha}), \mathrm{X}_{2}$ adalah Benih $(\mathrm{Kg}), X_{3}$ adalah Pupuk Organik/kimia $(\mathrm{Kg}), \mathrm{X}_{4}$ adalah Pestisida Organik/kimia (liter), $\mathrm{X}_{5}$ adalah Jumlah Tenaga Kerja (HOK), a adalah intercept, b1, b2,... adalah Nilai dugaan besaran parameter (koefisien regresi), dan U adalah error (kesalahan pengganggu).

\section{Analisis Biaya, Penerimaan, dan Pendapatan}

Untuk menganalisa biaya, penerimaan, dan pendapatan petani digunakan persamaan sebagai berikut:

$$
\begin{array}{ll}
\mathrm{Pd}=\mathrm{TR}-\mathrm{TC} & \mathrm{TC}=\mathrm{FC}+\mathrm{VC} \\
\mathrm{TR}=\mathrm{Y} . \mathrm{PY} & \mathrm{VC}=\mathrm{X} . \mathrm{PX}
\end{array}
$$

dimana Pd adalah Pendapatan (Rp), TR adalah Total penerimaan (Rp), TC adalah Total biaya (Rp), VC adalah Biaya variable (Rp), FC adalah Biaya tetap $(\mathrm{Rp}), \mathrm{Y}$ adalah Produksi (Kg) PY adalah Harga produksi (Rp), PX adalah harga input (Rp), dan $X$ adalah Jumlah input $(\mathrm{Kg})$.

\section{HASIL DAN PEMBAHASAN}

\section{Penggunaan Biaya dan Faktor Produksi Usahatani Padi}

Biaya produksi yang dianalisis dalam penelitian ini adalah biaya tetap dan biaya tidak tetap. Biaya tetap untuk sistem tanam SRI dan konvensional terdiri dari penyusutan alat-alat pertanian dan biaya pajak lahan. Biaya tidak tetap untuk sistem tanam SRI terdiri dari benih, bibit, pupuk organik, pestisida organik dan tenaga kerja. Sedangkan Biaya tidak tetap untuk sistem tanam konvensional terdiri dari benih, bibit, pupuk kimia, pestisida kimia dan tenaga kerja. Biaya produksi usahatani padi sawah dengan sistem tanam SRI dan Konvensional disajikan pada Tabel 1.

\section{Penggunaan dan Biaya Benih}

Dari hasil penelitian penggunaan benih rata-rata baik sistem tanam SRI maupun sistem Konvensional masing-masing, $12,53 \mathrm{Kg} / \mathrm{Ut}(19,88 \mathrm{Kg} / \mathrm{Ha})$ dan $21,71 \mathrm{Kg} / \mathrm{Ut}(30,00 \mathrm{Kg} / \mathrm{Ha})$. Pada tabel 2 di atas, dapat dilihat bahwa biaya benih padi sistem tanam SRI lebih sedikit dari biaya benih usahatani sistem konvensional, yaitu sebesar Rp 75.212,12 / Ut (Rp 119.515,15 /Ha) untuk sistem tanam SRI, dan Rp 135.342,11 /Ut (Rp 187.131,58 /Ha) untuk sistem tanam konvensional

Menurut “Centre for Agro Economic Research" (1988) dalam Sadli (2003) jumlah benih yang direkomendasikan untuk penanaman padi sistem tanam konvensional seluas satu hektar adalah sebanyak 25-30 Kg/ha. Penggunaan benih oleh petani di daerah penelitian ini sudah sesuai dengan kebutuhan benih perhektar yang direkomendasikan. Sedangkan untuk penggunaan benih oleh 
petani padi sawah sistem tanam SRI tidak sesuai dengan kebutuhan benih perhektar yang direkomendasikan pemerintah.

Tabel 1. Rata-Rata Penggunaan Faktor Produksi dan Biaya Usahatani Padi Sawah

\begin{tabular}{lllcc}
\hline No $\quad$ Faktor Produksi & Fisik/Ut & Fisik/Ha & \multicolumn{3}{c}{ Biaya } \\
\cline { 4 - 5 } & & Rp/Ut & Rp/Ha & $\%$
\end{tabular}

Sistem Tanam SRI

\begin{tabular}{|c|c|c|c|c|c|c|}
\hline & Benih $(\mathrm{Kg})$ & 12,52 & 19,88 & $75.212,12$ & $119.515,15$ & 2,55 \\
\hline & Pupuk (Kg) & 1484,85 & 2303,03 & $593.939,39$ & $921.212,12$ & 19,65 \\
\hline & Pestisida (Liter) & 1,30 & 2,06 & $13.030,30$ & $20.606,06$ & 0,44 \\
\hline & TKLK (HOK) & 33,10 & 51,09 & $1.318 .492,42$ & $2.055 .954,55$ & 43,85 \\
\hline & TKDK (HOK) & 17,87 & 28,41 & $817.340,91$ & $1.295 .924,24$ & 27,64 \\
\hline & Transportasi (Rp) & - & - & $178.606,06$ & $275.151,52$ & 5,87 \\
\hline 1. & Total Biaya Variabel & & & $2.996 .621,21$ & $4.688 .363,64$ & 100,00 \\
\hline & Pajak & - & - & $4.338,38$ & $6.722,22$ & 1,76 \\
\hline & Penyusutan Alat & - & - & $225.497,16$ & $375.294,95$ & 98,24 \\
\hline 2. & Total Biaya Tetap & & & $229.835,54$ & $382.017,18$ & 100,00 \\
\hline & Total Biaya (1+2) & & & $3.226 .456,75$ & $5.070 .380,81$ & \\
\hline
\end{tabular}

Sistem Tanam Konvensional

\begin{tabular}{|c|c|c|c|c|c|c|}
\hline & Benih (Kg) & 21,71 & 30,00 & $135.342,11$ & $187.131,58$ & 3,33 \\
\hline & Pupuk (Kg) & 314,47 & 428,95 & $825.328,95$ & $1.128 .245,61$ & 20,10 \\
\hline & Pestisida (Liter) & 5,62 & 7,34 & $662.831,58$ & $892.856,14$ & 15,91 \\
\hline & TKLK (HOK) & 33,44 & 45,31 & $1.424 .362,29$ & $1.927 .240,98$ & 34,34 \\
\hline & TKDK (HOK) & 17,73 & 25,15 & $815.855,26$ & $1.150 .679,85$ & 20,50 \\
\hline & Transportasi & & & $241.263,16$ & $326.157,89$ & 5,81 \\
\hline 1. & Total Biaya Variabel & & & $4.104 .983,34$ & $5.612 .312,04$ & 100,00 \\
\hline & Pajak & - & - & $5.271,93$ & $7.283,63$ & 2,55 \\
\hline & Penyusutan Alat & - & - & $192.205,43$ & $278.742,32$ & 97,45 \\
\hline 2. & Total Biaya Tetap & & & $197.477,36$ & $286.025,94$ & 100,00 \\
\hline & Total Biaya $(1+2)$ & & & $4.302 .460,70$ & $5.898 .337,98$ & \\
\hline
\end{tabular}

\section{Penggunaan Biaya Pupuk}

Jenis pupuk yang digunakan petani padi sawah dengan sistem tanam SRI di daerah penelitian adalah pupuk organik yaitu pupuk kandang. Sedangkan pupuk yang digunakan petani untuk padi sawah sistem tanam konvensional adalah pupuk kimia yaitu pupuk Urea, SP36, KCL, dan Phonska.

Pada kenyataannya usahatani padi sawah dengan sistem tanam SRI yang dilakukan oleh petani tidak mengalokasikan biaya pupuk. Hal ini karena pupuk organik diperoleh gratis dari pemerintah dan juga diolah sendiri oleh petani. Namun dalam penelitian ini, penggunaan pupuk tetap diperhitungkan sebagai biaya, dimana harga beli pupuk ditentukan dari harga jual pupuk organik di 
warung saprodi. Rata-rata penggunaan pupuk pada usahatani SRI dan konvensional sebesar 1.484,85 kg/Ut/Mt atau 2.303,03 Kg/Ha/Mt dan 314,47 $\mathrm{Kg} / \mathrm{Ut} / \mathrm{Mt}$ atau $428,95 \mathrm{Kg} / \mathrm{Ha} / \mathrm{Mt}$. Sedangkan untuk biaya rata-rata pupuk organik yang diperhitungkan dalam usahatani sistem tanam SRI sebesar Rp 593.939,39/Ut atau 921.212,12/Ha. Sedangkan petani padi sawah sistem tanam konvensional mengalokasikan biaya pupuk rata-rata sebesar Rp 825.328,95/Ut atau rata-rata sebesar $\operatorname{Rp} 1.128 .245,61 / \mathrm{Ha}$.

Jika dilihat dari penggunaan pupuk pada usahatani padi sawah sistem tanam konvensional pupuk yang banyak digunakan oleh petani di daerah penelitian adalah jenis pupuk Urea sebesar 208,77 Kg/Ha, kemudian jenis pupuk SP36 sebesar 89,04 Kg/Ha, dan yang paling sedikit adalah Phoska sebesar 59,21 Kg/Ha. Banyaknya penggunaan pupuk Urea yang digunakan oleh petani padi sawah diduga karena pada umumnya petani memiliki SDM yang rendah dimana petani beranggapan bahwa penggunaan dosis pupuk urea dengan jumlah yang banyak dapat mempercepat pertumbuhan dan peningkatan produksi padi sawah. Namun dalam kenyataannya penggunaan pupuk urea secara berlebihan dapat menyebabkan kesuburan tanah berkurang. Untuk lebih jelasnya lihat Tabel 2.

Tabel 2. Penggunaan dan Biaya Rata-rata Pupuk Usahatani Padi Sistem SRI dan Konvensional di Desa Bukit Peninjauan I Kec. Sukaraja Kab. Seluma

\begin{tabular}{|c|c|c|c|c|c|c|}
\hline $\begin{array}{l}\text { Sistem } \\
\text { Tanam }\end{array}$ & $\begin{array}{l}\text { Jenis } \\
\text { Pupuk }\end{array}$ & $\mathrm{Kg} / \mathrm{Ut}$ & $\mathrm{Kg} / \mathrm{Ha}$ & $\begin{array}{c}\text { Biaya } \\
\text { (Rp/Ut/Mt) }\end{array}$ & $\begin{array}{c}\text { Biaya } \\
\text { Rp/ha/Mt) }\end{array}$ & $(\%)$ \\
\hline Sistem SRI & $\begin{array}{c}\text { Pupuk } \\
\text { Organik }\end{array}$ & 1484,85 & 2303,03 & $593.939,39$ & $921.212,12$ & 100,00 \\
\hline & Urea & 153,29 & 208,77 & $263.223,68$ & $359.035,09$ & 31,82 \\
\hline Sistem & SP36 & 65,79 & 89,04 & $147.763,16$ & $193.684,21$ & 17,17 \\
\hline Konvensional & KCL & 54,61 & 74,56 & $323.947,37$ & $443.684,21$ & 39,32 \\
\hline & Phoska & 40,79 & 59,21 & $90.394,74$ & $131.842,11$ & 11,69 \\
\hline \multicolumn{2}{|c|}{ Jumlah } & 314,47 & 428,95 & $825.328,95$ & $1.128 .245,61$ & 100,00 \\
\hline
\end{tabular}

\section{Penggunaan Biaya Pestisida}

Rata-rata penggunaan pestisida (Tabel 3) pada kedua sistem usahatani jauh berbeda, dimana penggunaan pestisida sistem SRI lebih sedikit dari konvensional yaitu 1,30 Lt/Ut (2,06 Lt/Ha) dan 5,62 Lt/Ut (7,34 Lt/Ha). Perbedaan tersebut disebabkan karena dalam pengendalian hama dan penyakit tanaman petani padi sistem tanam SRI lebih sering menggunakan pengendalian secara fisik yaitu dengan mencabut gulma yang mengganggu tanaman dan melakukan pengasapan di sore hari. Selain itu petani padi sistem tanam SRI di daerah penelitian juga cukup sulit memperoleh pestisida organik. Sehingga petani padi sistem tanam SRI tidak menggunakan pestisida organik dengan jumlah yang banyak. Sedangkan biaya yang dikeluarkan petani padi sawah 
sistem tanam SRI untuk membeli pestisida adalah rata-rata sebesar Rp 13.030.30/Ut/Mt atau Rp 20.606,06/ha/Mt. Sedangkan biaya yang dikeluarkan petani padi sawah sistem tanam konvensional untuk membeli pestisida adalah rata-rata sebesar Rp 662.831,58/Ut/Mt atau Rp 892.856,14/ha/Mt. Berdasarkan tabel di atas, pestisida yang banyak digunakan oleh petani padi sawah sistem tanam konvensional yaitu Decis sebesar 85,47 \%, kemudian pestisida merek Tron sebesar 6,46 \%, dan yang paling sedikit adalah Score sebesar 1,35\%. Banyaknya biaya yang dikeluarkan untuk pestisida Decis karena harganya murah dan mudah terjangkau oleh petani. Sedangkan penggunaan biaya pestisida Score sedikit karena harganya mahal.

Tabel 3. Rata-rata Penggunaan dan Biaya Pestisida Usahatani Padi Sawah di Desa Bukit Peninjauan I Kec. Sukaraja Kab. Seluma

\begin{tabular}{llrrrrr}
\hline $\begin{array}{c}\text { Sistem } \\
\text { Tanam }\end{array}$ & $\begin{array}{c}\text { Jenis } \\
\text { Pestisida }\end{array}$ & Lt/Ut & Lt/Ha & $\begin{array}{c}\text { Biaya } \\
\text { (Rp/Ut/Mt) }\end{array}$ & $\begin{array}{c}\text { Biaya } \\
\text { Rp/ha/Mt) }\end{array}$ & $(\%)$ \\
\hline Sistem SRI & $\begin{array}{l}\text { Pestisida } \\
\text { Organik }\end{array}$ & 1,30 & 2,06 & $13.030,30$ & $20.606,06$ & 100,00 \\
& Decis & 2,80 & 3,82 & $560.526,63$ & $763.157,89$ & 85,47 \\
\multirow{3}{*}{ Sistem } & Tron & 1,84 & 2,31 & $46.052,63$ & $57.675,44$ & 6,46 \\
Konvensional & Spontan & 0,32 & 0,42 & $25.263,16$ & $34.736,84$ & 3,90 \\
& Score & 0,05 & 0,07 & $9.805,26$ & $12.110,53$ & 1,35 \\
& Gramacon & 0,61 & 0,71 & $21.184,21$ & $25.175,44$ & 2,82 \\
\hline & Jumlah & 5,62 & 7,34 & $662.831,58$ & $892.856,14$ & 100,00 \\
\hline
\end{tabular}

\section{Penggunaan dan Biaya Tenaga Kerja}

Berdasarkan hasil penelitian dapat diketahui bahwa rata-rata biaya tenaga kerja dalam keluarga yang dikeluarkan oleh petani padi sawah sistem tanam SRI untuk satu kali musim tanam adalah sebesar Rp 817.340,91/Ut atau sebesar Rp 1.295.924,24/Ha. Dan biaya rata-rata yang dikeluarkan untuk tenaga kerja luar keluarga adalah sebesar Rp 1.318.492,42/Ut atau sebesar Rp 2.055.954,55/Ha. Sedangkan untuk petani padi sawah sistem tanam konvensional biaya rata-rata yang dikeluarkan untuk tenaga kerja dalam keluarga adalah sebesar Rp $815.855,26 /$ Ut atau Rp 1.150.679,82/Ha. Dan biaya rata-rata yang dikeluarkan untuk tenaga kerja luar keluarga adalah sebesar Rp 1.424.362,29/Ut atau Rp 1.927.240,98/Ha. Jika di lihat dari nilai rata-rata penggunaan tenaga kerja (HOK) penggunaan tenaga kerja dalam keluarga sistem tanam SRI yaitu 19,55 $\mathrm{HOK} / \mathrm{Ut} / \mathrm{Mt}$ atau 31,37 $\mathrm{HOK} / \mathrm{Ha} / \mathrm{Mt}$ dan penggunaan tenaga kerja luar keluarga sistem tanam SRI yaitu 33,10 HOK/Ut/ Mt atau 51,27 HOK/Ha/ Mt sedangkan penggunaan tenaga kerja dalam keluarga sistem tanam konvensional yaitu 17,43 HOK/Ut/Mt atau 24,61 HOK/Ha/Mt dan penggunaan tenaga kerja luar keluarga sistem tanam konvensional yaitu 33,43 HOK/Ut/Mt atau 45,31 $\mathrm{HOK} / \mathrm{Ha} / \mathrm{Mt}$. Adanya perbedaan penggunaan tenaga kerja pada kedua sistem tanam tersebut karena pada sistem tanam SRI membutuhkan tenaga kerja yang lebih banyak untuk pemupukan. Hal ini karena pada sistem tanam SRI 
menggunakan pupuk organik dengan jumlah yang lebih banyak dari pupuk yang digunakan pada usahatani padi sistem konvensional.

Tabel 4. Rata-rata Biaya Tenaga Kerja Usahatani Padi Sawah Sistem SRI dan Konvensional di Desa Bukit Peninjauan I Kec. Sukaraja Kab. Seluma

\begin{tabular}{|c|c|c|c|c|c|}
\hline \multirow[b]{2}{*}{ Uraian } & \multicolumn{2}{|c|}{$\mathrm{HOK}$} & \multicolumn{3}{|c|}{ Jumlah Rata-Rata } \\
\hline & $\mathrm{Ut} / \mathrm{Mt}$ & $\mathrm{Ha} / \mathrm{Mt}$ & $(\mathrm{Rp} / \mathrm{Ut} / \mathrm{Mt})$ & $(\mathrm{Rp} / \mathrm{Ha} / \mathrm{Mt})$ & $\%$ \\
\hline \multicolumn{6}{|c|}{ Sistem Tanam SRI } \\
\hline \multicolumn{6}{|l|}{ 1. TK Dlm Keluarga } \\
\hline Pengolahan Lahan & 2,32 & 3,58 & $116.098,48$ & $179.166,67$ & 13,82 \\
\hline Penanaman & 0,53 & 0,87 & $15.886,36$ & $26.113,64$ & 2,02 \\
\hline Penyulaman & 0,79 & 1,25 & $23.795,45$ & $37.500,00$ & 2,89 \\
\hline Pemupukan I \& II & 5,96 & 9,10 & $298.484,84$ & $454.545,46$ & 35,08 \\
\hline Penyemprotan I \& II & 4,52 & 7,28 & $226.136,36$ & $364.393,94$ & 28,12 \\
\hline Penyiangan I \& II & 1,92 & 3,18 & $57.681,82$ & $95.454,54$ & 7,36 \\
\hline Panen & 3,51 & 6,11 & $79.257,58$ & $138.750,00$ & 10,71 \\
\hline Total TKDK & 19,55 & 31,37 & $817.340,91$ & $1.295 .924,24$ & 100,00 \\
\hline \multicolumn{6}{|l|}{ 2. TK Luar Keluarga } \\
\hline Pengolahan Lahan & 6,67 & 10,24 & $413.636,36$ & $650.000,00$ & 31,62 \\
\hline Penanaman & 8,65 & 13,53 & $259.636,36$ & $405.818,18$ & 19,74 \\
\hline Penyulaman & 2,20 & 3,27 & $66.000,00$ & $98.181,82$ & 4,78 \\
\hline Pemupukan I \& II & 0,24 & 0,24 & $12.121,22$ & $12.121,22$ & 0,59 \\
\hline Penyemprotan I \& II & 0,12 & 0,12 & $6.060,6$ & $6.060,6$ & 0,29 \\
\hline Penyiangan I \& II & 4.22 & 6,58 & $126.545,46$ & $197.454,54$ & 9,60 \\
\hline Panen & 11,00 & 17,29 & $434.492,42$ & $686.318,18$ & 33,38 \\
\hline Total TKLK & 33,10 & 51,27 & $1.318 .492,42$ & $2.055 .954,55$ & 100,00 \\
\hline Total Tenaga Kerja & 52,65 & 82,64 & $2.135 .833,33$ & $3.351 .878,79$ & \\
\hline \multicolumn{6}{|c|}{ Sistem Tanam Konvensional } \\
\hline \multicolumn{6}{|l|}{ 1. TK Dlm Keluarga } \\
\hline Pengolahan Lahan & 3,19 & 4,41 & $159.703,95$ & $220.339,91$ & 19,16 \\
\hline Penanaman & 0,51 & 0,72 & $15.157,89$ & $21.671,05$ & 1,88 \\
\hline Penyulaman & 0,62 & 0,92 & $20.532,89$ & $30.366,23$ & 2,64 \\
\hline Pemupukan I \& II & 5,02 & 7,16 & $251.315,78$ & $357.785,08$ & 31,09 \\
\hline Penyemprotan I \& II & 5,10 & 7,18 & $254.605,26$ & $358.662,28$ & 31,17 \\
\hline Penyiangan I \& II & 1,74 & 2,34 & $57.078,94$ & $75.526,32$ & 6,56 \\
\hline Panen & 1,25 & 1,88 & $57.460,53$ & $86.328,95$ & 7,50 \\
\hline Total TKDK & 17,43 & 24,61 & $815.855,26$ & $1.150 .679,82$ & 100,00 \\
\hline \multicolumn{6}{|l|}{ 2. TK Luar Keluarga } \\
\hline Pengolahan Lahan & 6,42 & 8,74 & $478.974,37$ & $650.000,00$ & 33,73 \\
\hline Penanaman & 10,29 & 13,92 & $308.782,89$ & $417.631,58$ & 21,67 \\
\hline Penyulaman & 2,32 & 3,07 & $69.513,16$ & $92.052,63$ & 4,78 \\
\hline Pemupukan I \& II & 0,20 & 0,26 & $10.197,36$ & $12.828,94$ & 0,66 \\
\hline Penyemprotan I \& II & 0,30 & 0,38 & $14.802,64$ & $18.969,30$ & 0,98 \\
\hline Penyiangan I \& II & 6,61 & 8,99 & $198.532,9$ & $269.802,63$ & 14,00 \\
\hline Panen & 7,29 & 9,95 & $343.985,97$ & $465.955,90$ & 24,18 \\
\hline Total TKLK & 33,43 & 45,31 & $1.424 .362,29$ & $1.927 .240,98$ & 100,00 \\
\hline Total Tenaga Kerja & 50,86 & 69,92 & $2.240 .217,55$ & $3.077 .920,80$ & \\
\hline
\end{tabular}




\section{Biaya Transportasi}

Biaya transportasi yang digunakan oleh petani adalah untuk membayar biaya angkut hasil panen padi dari lahan ke rumah petani. Berdasarkan informasi yang diperoleh di lapangan, petani di daerah penelitian menggunakan motor/ojek dalam mengangkut hasil panen padi. Rata-rata biaya yang dikeluarkan untuk usahatani padi sawah sistem tanam SRI adalah Rp 178.606,06 Ut/Mt atau Rp 275.151,52 Ha/Mt sedangkan rata-rata biaya yang dikeluarkan untuk usahatani padi sawah sistem tanam konvensional adalah Rp 241.263,16 Ut/Mt atau Rp 326.157,89 Ha/Mt. Besarnya biaya transportasi yang dikeluarkan petani untuk usahatani padi sawah tergantung pada jarak lahan dan ukuran karung yang digunakan petani. Jarak lahan yang jauh dari rumah petani akan meningkatkan biaya tranportasi dan sebaliknya jarak lahan yang dekat dari rumah petani akan menurunkan biaya tranportasi.

\section{Biaya Tetap}

\section{Biaya Penyusutan Alat}

Biaya penyusutan petani per musim tanam di Desa Bukit Peninjauan I dapat dilihat pada Tabel 5 berikut ini.

Tabel 5. Rata-rata Biaya Penyusutan Alat Usahatani Padi Sawah Sistem SRI dan Konvensional di Desa Bukit Peninjauan I Kec. Sukaraja Kab. Seluma

\begin{tabular}{llrrrr}
\hline \multirow{2}{*}{ No } & \multirow{2}{*}{ Jenis Alat } & \multicolumn{2}{c}{ Sistem SRI } & \multicolumn{2}{c}{ Sistem Konvensional } \\
\cline { 3 - 6 } & & $(\mathrm{Rp} / \mathrm{Ut} / \mathrm{Mt})$ & $(\mathrm{Rp} / \mathrm{Ha} / \mathrm{Mt})$ & $(\mathrm{Rp} / \mathrm{Ut} / \mathrm{Mt})$ & $(\mathrm{Rp} / \mathrm{Ha} / \mathrm{Mt})$ \\
\hline 1. & Cangkul & $12.968,01$ & $22.998,32$ & $13.491,84$ & $20.040,58$ \\
2. & Parang & $15.479,80$ & $24.474,75$ & $6.683,48$ & $10.264,38$ \\
3. & Handsprayer & $24.463,70$ & $37.634,67$ & $20.215,74$ & $30.250,91$ \\
4. & Sabit & $11.095,96$ & $19.296,30$ & $9.352,34$ & $14.928,36$ \\
5. & Trepal & $95.430,84$ & $158.036,06$ & $74.929,87$ & $106.782,25$ \\
6. & Karung & $66.058,85$ & $108.557,09$ & $67.532,16$ & $93.931,29$ \\
\hline & Total & $225.497,16$ & $375.294,95$ & $192.205,43$ & $278.742,32$ \\
\hline
\end{tabular}

Berdasarkan Tabel 5 di atas dapat dilihat bahwa biaya penyusutan alatalat pada usahatani padi sawah sistem tanam SRI dan konvensional paling banyak terdapat pada trepal yaitu Rp 95.430,84/Ut atau Rp 158.036,06/Ha, dan biaya penyusutan alat pada usahatani padi sawah sistem tanam konvensional yaitu Rp 74.929,87/Ut atau Rp 106.782,25/Ha. Hal ini karena harga beli trepal sangat mahal dan umur ekonomis dari trepal sangat sedikit sehingga menyebabkan biaya penyusutan alat tinggi. Trepal digunakan untuk tempat penjemuran padi. Pada umumnya padi diangkut dari lahan ke rumah masingmasing petani kemudian dijemur di halaman rumah masing-masing. 


\section{Biaya Pajak Lahan}

Di daerah penelitian status kepemilikan lahan adalah milik sendiri, oleh kerena itu dikenakan pajak lahan. Besarnya biaya pajak lahan yang dikeluarkan tergantung pada luas lahan. Rata-rata besarnya biaya pajak lahan yang dikeluarkan oleh petani dalam usahatani padi sawah sistem tanam SRI adalah sebesar Rp 4.338,38 /Ut/Mt atau sebesar Rp 6.722,22/Ha/Mt. Sedangkan ratarata besarnya biaya pajak lahan yang dikeluarkan oleh petani dalam usahatani padi sawah sistem tanam konvensional adalah sebesar Rp 5.271,93 /Ut/Mt atau sebesar Rp 7.283,63/Ha/Mt. Besarnya biaya pajak lahan yang dikeluarkan tergantung pada letak lahan dengan jalan lintas warga Desa Bukit Peninjauan I. Kondisi di lapangan menunjukkan bahwa letak lahan petani padi sistem konvensional lebih banyak yang dekat dengan jalan lintas warga Desa Bukit Peninjauan I. Letak lahan yang dekat dengan jalan lintas warga ini akan meningkatkan biaya pajak lahan demikian sebaliknya letak lahan yang jauh dengan jalan lintas warga pajaknya relatif lebih murah.

\section{Total Biaya Usahatani Padi Sawah}

Berdasarkan tabel 10 rata-rata total biaya dalam usahatani padi sawah sistem tanam SRI adalah sebesar $\mathrm{Rp} 3.226 .456,75 / \mathrm{Ut} / \mathrm{Mt}$ atau $\mathrm{Rp}$ $5.070 .380,81 / \mathrm{Ha} / \mathrm{Mt}$. Sedangkan Rata-rata total biaya dalam usahatani padi sawah sistem tanam konvensional adalah sebesar Rp 4.302.460,70 Ut/Mt atau Rp 5.898.337,98/Ha/Mt. Rata-rata total biaya usahatani padi sawah sistem tanam SRI lebih sedikit dari rata-rata total biaya usahatani padi sawah sistem tanam konvensional. Hal ini karena penggunaan biaya pestisida usahatani sistem tanam SRI lebih sedikit.

\section{Produksi dan Penerimaan Usahatani Padi Sawah Sistem Tanam SRI dan Konvensional}

Adapun jenis gabah yang sering dijual oleh petani di Desa Bukit Peninjauan I biasanya adalah GKG atau dalam bentuk beras. Hal ini karena petani di daerah penelitian sulit mendapatkan pemasaran padi dalam bentuk gabah basah atau gabah kering panen (GKP). Berdasarkan informasi yang diperoleh dari petani diketahui bahwa jumlah hasil panen petani padi sawah sistem tanam SRI ternyata lebih rendah dari hasil panen yang diperoleh petani padi sawah sistem konvensional. Dari rata-rata luas lahan yang diusahakan petani padi sawah sistem tanam SRI yakni seluas 0,64 hektar hanya mampu menghasilkan gabah kering giling (GKG) sebesar 35,91 Karung /30Kg atau sebesar 55,97 Karung/30Kg. Bila dikonversikan kedalam satuan kilogram maka produktivitas tanaman padi sawah sistem SRI menghasilkan GKG sebesar $1.077,3 \mathrm{Kg} / \mathrm{Ut} / \mathrm{Mt}$ atau $1.679,1 \mathrm{Kg} / \mathrm{Ha} / \mathrm{Mt}$.

Sedangkan rata-rata luas lahan yang diusahakan petani padi sawah sistem tanam konvensional yakni seluas 0,74 hektar mampu menghasilkan gabah kering giling (GKG) sebesar 44,26 Karung /30Kg/Ut/Mt atau sebesar 60,94 
Karung/30Kg/Ha/Mt. Bila dikonversikan kedalam satuan kilogram maka produktivitas tanaman padi sawah sistem konvensional menghasilkan GKG sebesar 1.327,8 Kg/Ut/Mt atau 1.828,2 Kg/Ha/Mt. Seperti yang ditunjukkan pada tabel 7 di bawah ini. Jumlah ini lebih besar dari hasil yang diperoleh petani padi sawah sistem tanam SRI. Jumlah produksi yang dihasilkan petani padi sawah sistem tanam SRI ternyata tidak sesuai dengan teori yang mengatakan bahwa dengan menggunakan metode SRI maka jumlah produktivitas padi akan meningkat. Hal ini disebabkan karena lahan petani masih dalam proses konversi sehingga masih ada pengaruh sistem konvensional yang menyebabkan belum dapat menghasilkan produksi yang tinggi. Di daerah penelitian sistem tanam SRI masih pada tahap menjaga kesuburan tanah. Produksi tinggi yang diharapkan akan terlihat setelah penerapan metode SRI terlaksana beberapa kali dengan konsep SRI yang benar. Karena pada kenyataannya petani di daerah penelitian belum sepenuhnya menerapkan konsep SRI dengan benar. Hal ini karena pengetahuan petani tentang penerapan SRI yang baik belum maksimal. Kondisi ini dapat dijelaskan dengan penggunaan pupuk organik yang tidak sesuai anjuran, kurangnya penggunaan pestisida organik karena kurangnya pengetahuan petani tentang pembuatan pestisida organik, dan penggunaan benih yang tidak sesuai rekomendasi.

Tabel 6. Rata-rata Produksi Usahatani Padi Sawah Sistem SRI dan Konvensional di Desa Bukit Peninjauan I Kec. Sukaraja Kab. Seluma

\begin{tabular}{cccc}
\hline \multirow{2}{*}{ No. } & \multirow{2}{*}{ Sistem Tanam } & \multicolumn{2}{c}{ Produksi Padi GKG } \\
\cline { 3 - 4 } & & $\mathrm{Kg} / \mathrm{Ut} / \mathrm{Mt}$ & $\mathrm{Kg} / \mathrm{Ha} / \mathrm{Mt}$ \\
\hline 1. & Sistem SRI & $1.077,27$ & $1.679,1$ \\
2. & Sistem Konvensional & $1.327,89$ & $1.828,2$ \\
\hline
\end{tabular}

Penerimaan petani padi sawah sistem tanam SRI dan konvensional di Desa Bukit Peninjauan I diperoleh dari nilai total produksi padi GKG dikali dengan harga jual beras. Petani padi sawah di Desa Bukit Peninjaun I memperoleh penerimaan dari hasil produksi padi yang telah dikeringkan dan digiling atau sering disebut dengan gabah kering giling (GKG). Selain dari produksi padi GKG, petani di Desa Bukit Peninjauan I juga memperoleh penerimaan dari penjualan dedak padi. Dedak padi diperoleh dari kulit gabah kering yang digiling untuk menghasilkan beras. Sehingga dalam hal ini petani memperoleh penerimaan tambahan selain dari penjualan padi GKG (Beras). Untuk lebih jelasnya rata-rata penerimaan usahatani yang diperoleh oleh petani di Desa Bukit Peninjauan I dapat dilihat pada Tabel 7.

Jika dilihat dari hasil penerimaan per hektar ternyata padi sistem tanam SRI lebih kecil jika dibandingkan dengan padi konvensional yaitu Rp 11.365.454,55/Ha/Mt untuk sistem tanam SRI dan Rp 12.276.105,26/Ha/Mt untuk sistem konvensional. Hal ini karena produksi yang dihasilkan usahatani padi sistem tanam SRI lebih kecil dari sistem tanam konvensional. 
Tabel 7. Rata-rata Penerimaan Usahatani Padi Sawah Sistem SRI dan Konvensional di Desa Bukit Peninjauan I Kec. Sukaraja Kab. Seluma

\begin{tabular}{llrrrr}
\hline \multirow{2}{*}{ No } & Jenis Penerimaan & \multicolumn{4}{c}{ Sistem Tanam } \\
\cline { 3 - 6 } & & \multicolumn{3}{c}{ Sistem SRI } & \multicolumn{2}{c}{ Sistem Konvensional } \\
\cline { 2 - 5 } & & $\mathrm{Rp} / \mathrm{Ut} / \mathrm{Mt}$ & $\mathrm{Rp} / \mathrm{Ha} / \mathrm{Mt}$ & \multicolumn{1}{c}{$\mathrm{Rp} / \mathrm{Ut} / \mathrm{Mt}$} & \multicolumn{1}{c}{$\mathrm{Rp} / \mathrm{Ha} / \mathrm{Mt}$} \\
\hline 1. & Gabah Kering Giling & $6.763 .636,36$ & $10.370 .909,09$ & $8.147 .368,42$ & $11.021 .052,63$ \\
2. & Dedak & $650.909,09$ & $994.545,45$ & $923.052,63$ & $1.255 .052,63$ \\
\hline & Total Penerimaan & $7.414 .545,45$ & $11.365 .454,55$ & $9.070 .421,05$ & $12.276 .105,26$ \\
\hline
\end{tabular}

\section{Analisis Pendapatan Usahatani Padi Sawah Sistem Tanam SRI dan Konvensional}

Pendapatan usahatani adalah selisih antara penerimaan usahatani dengan total biaya produksi yang telah dikeluarkan selama proses produksi berlangsung. Penerimaan yang tinggi belum tentu pendapatan yang diterima juga tinggi karena pendapatan ditentukan oleh penerimaan dan total biaya produksi secara bersama-sama. Tabel 8 menyajikan rata-rata pendapatan usahatani padi sawah sistem tanam SRI dan konvensional.

Tabel 8. Rata-rata Pendapatan Usahatani Padi Sawah Sistem Tanam SRI dan Konvensional di Desa Bukit Peninjauan I Kec. Sukaraja Kab. Seluma

\begin{tabular}{|c|c|c|c|}
\hline \multirow{2}{*}{ Sistem Tanam } & \multicolumn{3}{|c|}{ Keterangan (Rp./MT) } \\
\hline & Penerimaan & Total Biaya & Pendapatan \\
\hline \multicolumn{4}{|l|}{ Sistem SRI } \\
\hline UT & 7.414.545,45 & $3.226 .456,75$ & $4.188 .088,70$ \\
\hline HA & $11.365 .454,55$ & $5.070 .380,81$ & $6.295 .602,85$ \\
\hline \multicolumn{4}{|c|}{ Sistem Konvensional } \\
\hline UT & $9.070 .421,05$ & $4.302 .460,70$ & $4.767 .960,35$ \\
\hline HA & $12.276 .105,26$ & $5.898 .337,98$ & $6.368 .088,75$ \\
\hline
\end{tabular}

Dari data pada Tabel 8 diketahui bahwa pendapatan usahatani padi sawah sistem konvensional lebih besar dari pendapatan usahatani padi sawah sistem SRI. Rata-rata pendapatan usahatani padi sawah sistem tanam SRI adalah $\mathrm{Rp}$ 4.188.088,70/Ut/Mt atau Rp 6.295.602,85/Ha/Mt. Sedangkan rata-rata pendapatan usahatani padi sawah sistem tanam konvensional adalah $\mathrm{Rp}$ 4.767.960,35/Ut/Mt atau Rp 6.368.088,75/Ha/Mt. Adanya perbedaan pendapatan antara usahatani padi sawah sistem tanam SRI dan konvensional dikarenakan perbedaan rata-rata penerimaan dan rata-rata biaya total produksi yang dikeluarkan untuk kegiatan usahatani.

Evi Tinubaya L, Basuki Sigit Priyono, dan Witman Rasyid. Analisis ... | 198 


\section{Analisis Faktor Yang Mempengaruhi Produksi Usahatani Padi Sawah Sistem Tanam SRI Di Desa Bukit Peninjauan I}

Hasil analisis pendugaan tersebut disajikan pada tabel berikut:

Tabel 9. Hasil Pendugaan Fungsi Produksi Cobb-Douglass pada Usahatani Padi Sawah Sistem Tanam SRI di Desa Bukit Peninjauan I

\begin{tabular}{lrrr}
\hline Variabel Bebas & Koef Regresi & Std Error & \multicolumn{1}{r}{ T Hitung } \\
\hline Luas Lahan $\left(\mathrm{X}_{1}\right)$ & 1,0905 & 0,4305 & $2,533^{*}$ \\
Jumlah Benih $\left(\mathrm{X}_{2}\right)$ & $0,34435 \mathrm{E}-01$ & 0,1022 & 0,3369 \\
Jumlah Pupuk Organik $\left(\mathrm{X}_{3}\right)$ & $0,70913 \mathrm{E}-01$ & 0,1116 & 0,6355 \\
Jumlah Pestisida Organik $\left(\mathrm{X}_{4}\right)$ & $-0,19143$ & 0,2333 & $-0,8207$ \\
Jumlah TK $\left(\mathrm{X}_{5}\right)$ & $-0,13143 \mathrm{E}-01$ & 0,2819 & $-0,4663 \mathrm{E}-01$ \\
\hline Konstanta & 7,0039 & 1,613 & 4,343 \\
\hline R Square & & & 0,8816 \\
\hline F-hitung & & & 40,191 \\
\hline
\end{tabular}

Sumber : Analisis Regresi Linear Berganda (Lampiran 13), 2011

*) signifikan pada taraf kepercayaan 95\% untuk sistem SRI t-tabel $(0,025 ; 27): \pm 2,052 ;$ F-tabel : 2,571886

Hasil uji F pada usahatani sistem SRI juga menunjukkan bahwa $\mathrm{F}$ hitung $(40,191)$ lebih besar dari F tabel $(2,571)$ pada taraf kepercayaan $95 \%$ yang artinya secara statistik model fungsi produksi menunjukkan bahwa secara bersamasama jumlah luas lahan, jumlah bibit, jumlah pupuk organik, jumlah pestisida organik, dan jumlah tenaga kerja secara bersama-sama berpengaruh nyata terhadap produksi usahatani padi sawah sistem konvensional. Dengan demikian model yang digunakan sudah tepat dan layak untuk digunakan.

Nilai R2 (koefisien determinasi) yang diperoleh pada usahatani padi sawah sistem tanam SRI sebesar 0.8816 atau $88.16 \%$. Ini berarti bahwa $88.16 \%$ variasi faktor yang mempengaruhi variasi pendapatan usahatani padi sistem tanam SRI di Desa Bukit Peninjauan I dijelaskan oleh semua variabel bebas yang ada dalam model, sedangkan sisanya sebesar 11,84 \% dijelaskan oleh variabel lain yang tidak dimasukkan dalam model.

Hasil pengujian secara parsial dengan menggunakan uji-t pada usahatani padi sawah sistem tanam SRI padi adalah sebagai berikut :

\section{Luas Lahan}

Hasil pendugaan variabel luas lahan terhadap produksi usahatani padi sawah sistem tanam SRI menunjukkan bahwa nilai $\mathrm{t}$ hitung $>\mathrm{t}$ tabel $(2,533>$ 2,052), sehingga Ho ditolak dan Hi diterima artinya nilai variabel luas lahan berpengaruh nyata terhadap produksi usahatani padi. Nilai koefisien regresi sebesar 1,0905, yang berarti jika terjadi penambahan 1\% luas lahan maka akan menambahkan produksi sebesar 1,0905 \% dengan asumsi variabel yang lain konstan. 
Kondisi ini didukung oleh hasil penelitian Isyanto (2011) yang dilakukan di Desa Kawasen Kecamatan Banjarsari Kabupaten Ciamis yang memperoleh suatu fakta bahwa luas lahan berpengaruh nyata terhadap produksi padi di Desa Dusun Besar Kodia Bengkulu dan hasil penelitian Aprizal (1998) tentang produksi, pendapatan dan distribusi pendapatan petani padi sawah irigasi, kasus di Desa Tanjung Harapan Kecamatan Padang Jaya Kabupaten Bengkulu Utara, dalam kesimpulannya menyatakan bahwa luas lahan berpengaruh nyata terhadap produksi padi sawah irigasi di Desa Tanjung Harapan Kecamatan Padang Jaya Kabupaten Bengkulu Utara.

\section{Jumlah Benih}

Berdasarkan hasil uji $\mathrm{t}$ di atas usahatani padi sawah sistem tanam SRI menunjukkan bahwa nilai $\mathrm{t}$ hitung $<\mathrm{t}$ tabel $(0,3369<2,052)$, sehingga Ho diterima dan Hi ditolak artinya variabel jumlah benih tidak berpengaruh nyata terhadap produksi usahatani padi sawah. Berdasarkan pengamatan di lapangan, tidak berpengaruhnya jumlah benih terhadap produksi diduga karena benih yang tumbuh mengalami stress karena pada saat penanaman benih tidak diperlakukan sesuai aturan teknik penanaman sistem tanam SRI dengan benar. Dimana seharusnya benih disemai di dalam nampan, kemudian pada saat benih dicabut dari nampan, benih tersebut harus langsung ditanam. Namun kondisi di lapangan berbeda, ketika dicabut, bibit tidak langsung ditanam sehingga mengakibatkan bibit mengalami stress sebelum ditanam. Keadaan demikian akan mempengaruhi pertumbuhan padi, dimana padi pada saat pertumbuhannya akan mengurangi anakan pada akar padi sehingga produksi akan menurun. Hal ini ditunjukkan dengan hasil uji yang menyatakan bahwa jumlah benih tidak berpengaruh nyata terhadap produksi padi.

\section{Jumlah Pupuk}

Hasil uji parsial terhadap penggunaan pupuk menunjukkan bahwa pupuk organik tidak berpengaruh nyata terhadap produksi usahatani padi sawah sistem tanam SRI. Kesimpulan ini ditunjukkan oleh hasil uji $t$, dimana nilai $t$ hitung < t tabel $(0,6355<2,052)$, sehingga Ho diterima dan Hi ditolak artinya variabel jumlah pupuk organik tidak berpengaruh nyata terhadap produksi usahatani padi sawah.

Dari hasil penelitian dapat diketahui bahwa tidak berpengaruhnya pupuk organik terhadap produksi padi sawah dikarenakan masih adanya pengaruh penggunaan pupuk anorganik yang sebelumnya digunakan oleh petani. Pengaruh penggunaan pupuk anorganik yang sebelumnya digunakan oleh petani ini berdampak pada proses kesuburan tanah. Dimana selama petani menggunakan pupuk anorganik, kondisi tanah dalam keadaan tidak stabil artinya pH tanah tidak normal. Dalam penelitian Ekamaida (2008) dikatakan bahwa hasil pengukuran $\mathrm{pH}$ tanah pada pola tanam SRI lebih tinggi dibandingkan dengan $\mathrm{pH}$ tanah pada sistem pertanian anorganik. Lebih rendahnya $\mathrm{pH}$ tanah pertanian anorganik disebabkan pemakaian pupuk pabrik 
terutama urea yang makin lama akan memasamkan tanah. Sehingga dalam hal ini dapat disimpulkan bahwa tidak berpengaruhnya pupuk organik terhadap produksi padi karena pemberian pupuk organik pada usahatani sistem tanam SRI belum mampu mengembalikan kesuburan tanah.

\section{Jumlah Pestisida}

Hasil pendugaan variabel jumlah pestisida organik terhadap produksi usahatani padi sawah sistem tanam SRI menunjukkan bahwa nilai $-\mathrm{t}$ hitung $>-\mathrm{t}$ tabel $(-0,8207>-2,052)$, sehingga Ho diterima dan Hi ditolak artinya variabel jumlah pestisida organik tidak berpengaruh nyata terhadap produksi usahatani padi sawah.

Dari hasil penelitian dapat diketahui bahwa penggunaan pestisida organik tidak mempengaruhi produksi, hal ini karena petani padi sistem tanam SRI di Desa Bukit Peninjauan I lebih sering memanfaatkan teknik pengasapan di sore hari dalam pemberantasan hama dari pada penggunaan pestisida organik. Seringnya petani memanfaatkan teknik pengasapan di sore hari dalam pemberantasan hama karena petani padi sawah sistem tanam SRI masih sulit memperoleh petisida organik. Sehingga pestisida organik/cair yang digunakan hanya sedikit, padahal hama dan penyakit yang terdapat di dalam tanaman cukup banyak tidak sebanding dengan penggunaan pestisida organik yang diberikan oleh petani. Dengan demikian pestisida organik tidak berpengaruh signifikan terhadap produksi padi sawah sistem SRI.

\section{Jumlah Tenaga Kerja}

Hasil pendugaan tipe Fungsi Cobb douglas menunjukkan bahwa jumlah tenaga kerja tidak memberikan pengaruh signifikan terhadap produksi padi sawah yang ditunjukkan dengan nilai -t hitung $>$-t tabel $(-0,04663>-2,052)$, sehingga Ho diterima dan Hi ditolak artinya variabel jumlah tenaga kerja tidak berpengaruh nyata terhadap produksi usahatani padi sawah. Hasil uji $t$ di atas menunjukkan bahwa penggunaan tenaga kerja tidak berpengaruh terhadap produksi padi sawah, ini dimungkinkan karena pencurahan tenaga kerja yang masih rendah. Menurut penelitian Tumiyati (2000) yang dilakukan di Kecamatan Padang Jaya Kabupaten Bengkulu Utara, rata-rata curahan tenaga kerja perhektar sampai mencapai 143,77 HOK sedangkan didaerah penelitian hanya mencapai $82,64 \mathrm{HOK}$. Jadi apabila tenaga kerja ini ditingkatkan masih memungkinkan untuk meningkatkan produksi.

Fakta di atas menunjukkan bahwa banyaknya jumlah tenaga kerja tidak selamanya berpengaruh positif terhadap produksi, namun sebaliknya penggunaan tenaga kerja dengan jumlah yang tidak sesuai keperluan, bisa mengakibatkan pengaruh yang negatif terhadap produksi. 


\section{Analisis Faktor Yang Mempengaruhi Produksi Usahatani Padi Sawah Sistem Tanam Konvensional Di Desa Bukit Peninjauan I}

Hasil estimasi fungsi produksi usahatani padi sawah dengan sistem konvensional disajikan pada tabel berikut :

Tabel 10. Hasil Pendugaan Fungsi Produksi Cobb-Douglass pada Usahatani Padi Sawah Sistem Tanam Konvensional di Desa Bukit Peninjauan I

\begin{tabular}{lrrr}
\hline Variabel Bebas & Kooefisen Regresi & Standar Error & \multicolumn{1}{c}{ T Hitung } \\
\hline Luas Lahan $\left(\mathrm{X}_{1}\right)$ & 1.4212 & 0.2803 & $5.070^{*}$ \\
Jumlah Benih $\left(\mathrm{X}_{2}\right)$ & $0.12133 \mathrm{E}-01$ & 0.1135 & 0.1069 \\
Jumlah Pupuk $\left(\mathrm{X}_{3}\right)$ & $-0.16205 \mathrm{E}-01$ & $0.9250 \mathrm{E}-01$ & -0.1752 \\
Jumlah Pestisida $\left(\mathrm{X}_{4}\right)$ & -0.11919 & 0.1264 & -0.9427 \\
Jumlah TK $\left(\mathrm{X}_{5}\right)$ & -0.37047 & 0.1735 & $-2.135^{*}$ \\
\hline Konstanta & 9.2482 & 1.055 & 8.766 \\
\hline R Square & \multicolumn{3}{c}{0.8970} \\
\hline F-hitung & \multicolumn{5}{c}{55.729} \\
\hline
\end{tabular}

Sumber : Analisis Regresi Linear Berganda (Lampiran 13), 2011

*) signifikan pada taraf kepercayaan $95 \%$ untuk sistem konvensional t-tabel $(0,025 ; 32): \pm 2,037$; F-tabel: 2,512255

Hasil uji $\mathrm{F}$ pada usahatani padi sawah sistem konvensional menunjukkan bahwa $\mathrm{F}$ hitung $(55,729)$ lebih besar dari $\mathrm{F}$ tabel $(2,512)$ pada taraf kepercayaan 95\% yang artinya secara statistik model fungsi produksi menunjukkan bahwa secara bersama-sama jumlah luas lahan, jumlah bibit, jumlah pupuk kimia, jumlah pestisida kimia, dan jumlah tenaga kerja secara bersama-sama berpengaruh nyata terhadap produksi usahatani padi sawah sistem konvensional. Dengan demikian model yang digunakan sudah tepat dan layak untuk digunakan.

Nilai $\mathrm{R}^{2}$ (koefisien determinasi) yang diperoleh pada usahatani padi sawah sistem tanam konvensional sebesar 0.8970 atau $89.70 \%$. Ini berarti bahwa $89.70 \%$ variasi faktor yang mempengaruhi variasi pendapatan usahatani padi sistem tanam konvensional di Desa Bukit Peninjauan I dijelaskan oleh semua variabel bebas yang ada dalam model, sedangkan sisanya sebesar 10,3\% dijelaskan oleh variabel lain yang tidak dimasukkan dalam model.

Hasil pengujian secara parsial dengan menggunakan uji-t pada usahatani padi sawah sistem tanam konvensional adalah sebagai berikut :

\section{Luas Lahan}

Berdasarkan hasil análisis pengaruh faktor produksi terhadap produksi usahatani padi sawah sistem tanam konvensional seperti tertera pada tabel 19 menunjukkan bahwa nilai $t$ hitung $>t$ tabel $(5,070>2,037)$, sehingga Ho ditolak dan Hi diterima artinya nilai variabel luas lahan berpengaruh nyata terhadap pendapatan usahatani padi. Nilai koefisien regresi sebesar 1,4212, yang berarti

Evi Tinubaya L, Basuki Sigit Priyono, dan Witman Rasyid. Analisis ... | 202 
jika terjadi penambahan $1 \%$ luas lahan maka akan menambahkan produksi sebesar 1,4212 \% dengan asumsi variabel yang lain konstan. Berpengaruhnya jumlah luas lahan terhadap produksi padi sawah sistem tanam konvensional di daerah penelitian, seiring dengan hasil penelitian Aprizal (1998) tentang produksi, pendapatan dan distribusi pendapatan petani padi sawah irigasi, kasus di Desa Tanjung Harapan Kecamatan Padang Jaya Kabupaten Bengkulu Utara, dalam kesimpulannya menyatakan bahwa luas lahan berpengaruh nyata terhadap produksi padi sawah irigasi di Desa Tanjung Harapan Kecamatan Padang Jaya Kabupaten Bengkulu Utara.

\section{Jumlah Benih}

Hasil pendugaan variabel jumlah benih terhadap produksi usahatani padi sawah sistem tanam konvensional menunjukkan bahwa nilai $\mathrm{t}$ hitung $<\mathrm{t}$ tabel $(0,1069<2,037)$, sehingga Ho diterima dan Hi ditolak artinya nilai variabel jumlah benih tidak berpengaruh nyata terhadap produksi usahatani padi sawah.

Kondisi ini didukung oleh hasil penelitian Susanti (1999) dalam Ratiem (2003) yang dilaksanakan di Desa Air Latak dan Desa Sukasari Kecamatan Sukaraja Bengkulu Selatan yang menghasilkan suatu kesimpulan bahwa jumlah benih tidak berpengaruh nyata terhadap produksi padi di kedua desa tersebut. Berdasarkan kondisi di lapangan menunjukkan jumlah penggunaan benih sebanyak 30,00 Kg/Ha/Mt telah mendekati rekomendasi yang dianjurkan pemerintah untuk tanaman padi sawah sistem konvensional, hanya saja penggunaan benih oleh petani yang telah ditanam mengalami gangguan yaitu serangan hama dan penyakit yang mengganggu setelah tanaman tumbuh dan saat mulai berbunga semakin membuat berkurangnya hasil panen yang diperoleh petani.

\section{Jumlah Pupuk}

Untuk faktor produksi pupuk kimia dengan hasil uji $\mathrm{t}$ menunjukkan bahwa nilai -t hitung $>-t$ tabel $(-0,1752>-2,037)$, sehingga Ho diterima dan Hi ditolak artinya nilai variabel jumlah pupuk kimia tidak berpengaruh nyata terhadap produksi usahatani padi sawah. Hal ini karena penggunaan pupuk oleh petani tidak sesuai dengan rekomendasi penyuluh pertanian di daerah penelitian. Berdasarkan rekomendasi pemerintah penggunaan pupuk yang baik adalah dengan jumlah pupuk urea sekitar $200 \mathrm{Kg} / \mathrm{ha}$, SP36 $150 \mathrm{Kg} / \mathrm{Ha}$, KCL 50 $\mathrm{Kg} / \mathrm{Ha}$, dan Phoska $100 \mathrm{Kg} / \mathrm{Ha}$. Sedangkan dalam penelitian ini penggunaan pupuk yaitu untuk pupuk urea 208,77 kg/ha, SP36 89,04 Kg/Ha, KCL 74,56 $\mathrm{Kg} / \mathrm{Ha}$, dan Phoska 59,21 Kg/Ha. Penggunaan pupuk dengan jumlah yang tidak sesuai rekomendasi ini diduga tidak memberikan pengaruh yang positif terhadap produksi padi, karena penggunaan pupuk dengan jumlah yang tidak sesuai dapat mengakibatkan tanah tidak subur sehingga anakan pada akar tanaman tidak bertambah banyak dan akibatnya produksi tidak meningkat.

Hasil analisis di atas didukung oleh hasil penelitian Triyanto (2006) tentang analisis produksi padi di Jawa Tengah dalam kesimpulannya 
menyatakan bahwa jumlah pupuk tidak berpengaruh terhadap produksi padi di Jawa Tengah. Kecilnya pengaruh jumlah pupuk terhadap produksi padi disebabkan karena mahalnya harga pupuk di daerah penelitian sehingga petani tidak mampu menggunakan pupuk yang banyak.

\section{Jumlah Pestisida}

Hasil estimasi fungsi produksi Cobb-Douglass pada usahatani padi sawah sistem tanam konvensional diketahui nilai $-t$ hitung > $-t$ tabel $(-0,9427>-2,037)$, sehingga Ho diterima dan $\mathrm{Hi}$ ditolak artinya nilai variabel jumlah pestisida kimia tidak berpengaruh nyata terhadap produksi usahatani padi sawah. Masih rendahnya penggunaan faktor produksi pestisida dalam proses produksi di daerah penelitian ini kemungkinan disebabkan karena harga pestisida di daerah penelitian cukup mahal sehingga petani tidak sanggup untuk membeli pestisida dengan jumlah yang banyak sedangkan hama dan penyakit yang ada dalam tanaman padi cukup banyak yang mengakibatkan tanaman tumbuh tidak sehat. Hal ini menyebabkan penggunaan pestisida yang sedikit tersebut tidak berpengaruh nyata terhadap produksi padi sawah sistem tanam konvensional.

\section{Jumlah Tenaga Kerja}

Hasil uji t terhadap penggunaan tenaga kerja terhadap produksi usahatani padi sawah sistem tanam konvensional menunjukkan bahwa nilai $-\mathrm{t}$ hitung $<-\mathrm{t}$ tabel $(-2,135<-2,037)$, sehingga Ho ditolak dan Hi diterima artinya nilai variabel jumlah tenaga kerja berpengaruh negatif terhadap produksi usahatani padi sawah. Nilai koefisien regresi sebesar -0,37047, yang berarti jika terjadi penambahan $1 \%$ jumlah tenaga kerja maka penambahan ini akan menyebabkan penurunan jumlah produksi sebesar 37,04 \%. Hal ini terjadi karena besarnya penggunaan tenaga kerja pada proses penyiangan. Penelitian Ratiem (2003) menunjukkan bahwa penggunaan tenaga kerja untuk proses penyiangan sebesar 3,06 HOK/Ha dan hasil ini berpengaruh positif terhadap produksi padi sawah. Sedangkan pada penelitian penggunaan tenaga kerja untuk proses penyiangan sebesar 11,33 $\mathrm{HOK} / \mathrm{Ha}$ dan hasil ini berpengaruh negatif terhadap produksi padi sawah sistem tanam konvensional. Adanya pengaruh negatif pada produksi usahatani padi sawah ini diduga karena pada saat pertumbuhan tanaman mengalami serangan hama/gulma yang relatif banyak tumbuh disekitar tanaman padi. Sehingga petani menggunakan tenaga kerja penyiangan dengan jumlah yang banyak. Namun hal ini tidak cukup untuk dapat mengembalikan kondisi tanaman padi menjadi lebih baik karena dibutuhkan juga penggunaan pestisida yang baik. Pada kenyataanya petani menggunakan pestisida dengan jumlah yang sedikit karena harga pestisida yang mahal sehingga petani tidak mampu untuk membeli pestisida dalam jumlah yang banyak untuk pengendalian hama dan penyakit tanaman padi. 


\section{SIMPULAN DAN SARAN}

\section{Simpulan}

Berdasarkan hasil penelitian usahatani padi sawah sistem tanam SRI yang dibandingkan dengan usahatani padi sistem tanam konvensional, maka disimpulkan bahwa:

1. Terdapat perbedaan rata-rata pendapatan usahatani padi sistem tanam SRI dan konvensional. Rata-rata pendapatan usahatani padi sistem tanam SRI lebih kecil dari usahatani padi sawah sistem tanam konvensional. Untuk rata-rata pendapatan usahatani padi sawah sistem tanam SRI sebesar Rp 4.188.088,70/Ut/Mt atau Rp 6.295.602,85/Ha/Mt. Sedangkan rata-rata pendapatan usahatani padi sawah sistem tanam konvensional adalah $\mathrm{Rp} 4.767 .960,35 / \mathrm{Ut} / \mathrm{Mt}$ atau $\mathrm{Rp}$ 6.368.088,75/Ha/Mt. Hal ini disebabkan karena sistem usahatani dengan menggunakan metoda SRI baru saja (2 kali musim tanam) diterapkan.

2. Hasil pengujian faktor-faktor yang mempengaruhi produksi pada usahatani padi sawah sistem tanam SRI dengan menggunakan uji-t untuk variabel yang berpengaruh nyata adalah luas lahan sedangkan jumlah benih, pupuk organik, pestisida organik, dan tenaga kerja tidak berpengaruh nyata. Sementara hasil pengujian untuk usahatani padi sawah sistem tanam konvensional dengan menggunakan uji $t$ untuk variabel yang berpengaruh nyata adalah luas lahan dan tenaga kerja sedangkan jumlah benih, pupuk kimia, pestisida kimia tidak berpengaruh nyata secara signifikan.

\section{Saran}

Perubahan sistem usahatani yang dilakukan oleh sebagian petani padi sawah di Desa Bukit Peninjauan I telah membawa perubahan yang positif terhadap perilaku petani dalam menjaga kesuburan tanah. Meskipun jumlah produksi yang dihasilkan oleh usahatani padi sistem tanam SRI masih lebih kecil dari sistem konvensional, namun petani padi tetap disarankan menggunakan sistem tanam SRI guna menjaga kesuburan tanah dan meningkatkan produksi dimasa yang akan datang. Namun untuk pengembangan usahatani padi sawah sistem tanam SRI sebaiknya petani lebih memperhatikan penerapan teknis budidaya padi sawah sistem tanam SRI dengan baik. Petani harus konsisten terhadap penerapan sistem tanam SRI seperti yang telah direkomendasikan oleh pemerintah, dan perhatian penyuluh dari pemerintah (Dinas Pertanian Kabupaten Seluma) terhadap petani harus lebih ditingkatkan.

\section{DAFTAR PUSTAKA}

Aprizal, 1998. Produksi, Pendapatan Dan Distribusi Pendapatan Petani Padi Sawah Irigasi ( Kasus di Desa Tanjung Harapan Kecamatan Padang Jaya Kabupaten 
Bengkulu Utara). Fakultas Pertanian. Universitas Bengkulu. Skripsi (tidak dipublikasikan)

Isyanto, Yuniawan, A.,2011. Estimasi Efisiensi Ekonomis Usahatani Padi SRI (System of Rice Intensification) (Studi Kasus Di Desa Kawasen Kecamatan Banjarsari Kabupaten Ciamis). http://widyagama.ac.id/pertanian/wpcontent/uploads/2012/01/ 1Agus.pdf (21 Januari 2012 11:53 AM)

Ratiem. 2003. Analisis Usahatani Padi Sawah dengan Sistem Tanam Yang Menggunakan Tanam Benih Langsung dan Yang menggunakan Pindah di Desa Rimbo Recap Kecamatan Curup Kabupaten Rejang Lebong. Fakultas Pertanian. Universitas Bengkulu. Skripsi (tidak dipublikasikan).

Sadli, M. 2003. Analisis Faktor-faktor Produksi Dan Efisiensi Usahatani Padi Sawah Pada Petani Anggota Dan Non Anggota Kelompok Tani (Studi Kasus Di Kelurahan Kemumu Kecamatan Kota Arga Makmur Bengkulu Utara). Fakultas Pertanian. Universitas Bengkulu. Skripsi (tidak dipublikasikan).

Tumiati. 2000. Analisis faktor-faktor Yang mempengaruhi produksi padi sawah di kelurahan keтumu kecamatan padang jaya kabupaten Bengkulu utara. Fakultas Pertanian. Universitas Bengkulu. Skripsi (tidak dipublikasikan).

Triyanto, Joko, 2006. Analisis Produksi Padi di Jawa Tengah. http://eprints.undip.ac.id/15686/1/Joko_Triyanto.pdf (07 Februari 2012. 12.03 PM) 